\title{
The Evaluation of a Self-Development Programme for Managers in a Corporate Pharmacy Group
}

\section{J Pienaar and S Rothmann}

School of Human Resource Sciences, Potchefstroom University for CHE

\section{JC Rothmann}

S Buys Training Academy, Potchefstroom

\section{ABSTRACT}

Changes that impact on organisations require of managers to accept responsibility for their self-development to remain effective. The aim of this research was to evaluate a self-development programme for managers in a corporate pharmacy group. A two-group true experimental design with pre-, post, and post-post testing was used. A total of 35 managers were randomly divided into an experimental $(n=18)$ and control group $(n=17)$. The following measuring instruments were used for the evaluation of the programme: The Personal Orientation Inventory, the Generalised Perceived Self-Efficacy Scale, the COPE-Questionnaire and a knowledge test. The results showed that participants showed higher Synergy and Feeling reflection and greater selfefficacy following the self-development programme.

JEL M00

\section{INTRODUCTION}

Managers increasingly face higher career demands. This is true for various professions, including pharmacists. Ferguson (1998) states that pharmacists must not only make a commitment to life-long professional development but also demonstrate an ability to adapt to developments in pharmacy, medicine and all other health-related disciplines. Grant (2000) emphasises that the striving for continuing professional development should be an internal quality of professionals and that they should naturally adapt to the concept of development and competence.

Möller, Rothmann, Rothmann, Coetzer and Swart (2000) recommended that development programmes for managers in pharmacy groups should start with self-development. A self-development programme forms the basis on which 
other training and development programmes for managers could build. A manager's effectiveness flows from his or her intra- and interpersonal effectiveness (Amos \& Mather, 1998), which are important aspects of selfdevelopment. Research in a corporate pharmacy group shows that most of the managers (who were trained as pharmacists) prefer a quiet environment, dislike intrusions and interruptions and experience some problems communicating (Rothmann, Rothmann, Van Rensburg \& Malan, 2000).

The above-mentioned personality characteristics are probably encouraged by pharmacy schools (Rothmann, Basson \& Rothmann, 2000) and may inhibit pharmacy managers from developing the competencies required for the roles they have to fulfil (Davidson, 2000). Möller et al. (2000) express concern that the pattern of introversion, neuroticism, a practical approach and inflexibility, combined with situational demands, role overload and pharmacists' responsibility for management and care, may result in resistance to change, interpersonal difficulties, an inability to control impulses, burnout and eventually impairment. Therefore, self-development programmes are necessary to stimulate the self-awareness, self-regard, self-acceptance, flexibility and interpersonal effectiveness to prevent the above-mentioned problems.

Self-development is also referred to as self-actualisation or psychologically optimal functioning (Rothmann \& Sieberhagen, 1997). Psychologically optimal functioning is defined as a positive and dynamic development process through which individuals reach clear self-concepts through feedback from the environment, where they can regard themselves positively while self-objectivity is still possible, and where they can have more effective interaction with the world surrounding them (Rothmann, 1999). Research (Cilliers \& Wissing, 1993; Rothmann \& Sieberhagen, 1997) shows that methods directed at facilitating psychologically optimal functioning are applicable to the stimulation of selfdevelopment.

Various theories could be used to conceptualise self-development. Analytical theory (Jung, 1971) focuses on opposing sub-systems (attitude and functions) within a person as a point of departure for self-development. A balance between these polarities and the transition of an outwardly-directed adaptation to an inwardly-directed adaptation can lead to a feeling of control over self and the external environment (Meyer, Moore \& Viljoen, 1994). Jung's theory (1971) relates the individuation process to self-development. Individuation not only comprises the initial development of dominant attitudes and functions, but also involves the consciousness of non-dominant attitudes and functions that lead to better adaptation and relationships (Day \& Matthes, 1992). Exposure to a form of sensitivity training eases this individuation process as individuals are encouraged to consciously experience their non-dominant attitudes and 
functions through continuous feedback from others. The consciousness of blind spots in the psyche leads to self-awareness (Day \& Matthes, 1992).

Self-development can take place through programmes directed at the stimulation of personal growth (including self-knowledge, self-esteem, self-efficacy and resilience) and coping (Strümpfer, 2000). Self-development is also a prerequisite for interpersonal effectiveness (Rothmann \& Sieberhagen, 1997). Interpersonal effectiveness could be improved by training in interpersonal skills and facilitative communication. Rogers's person-centred theory (1961) offers a structure for individual and group counselling aimed at self-development. According to this theory the individual moves away from the idea of living according to the standards of others towards the perception of him/herself as a self-directed person with standards and values formulated through own experiences (Rogers, 1973). Rothmann, Sieberhagen and Cilliers (1998) found that individuals accept greater responsibility based on the application of the methods of this theory in a training programme. Related to this, Cilliers and Wissing (1993) found that a development programme in sensitive relating contributes to psychological optimality.

Various self-development programmes were found in the literature. Jorgensen and Rothmann (1998), Rothmann and Sieberhagen (1997), Rothmann, Sieberhagen and Cilliers (1998) and Rothmann (1999) evaluated selfdevelopment programmes that were directed at the intra- and interpersonal effectiveness of facilitators. Furthermore, Olivier and Rothmann (1999) and Els, Linde and Rothmann (2001) evaluated self-development programmes directed at the stimulation of an internal locus of control. Although these development programmes showed promising results, none of them were directed at stimulating self-development of managers in a corporate pharmaceutical environment. Therefore a need exists to develop and evaluate a selfdevelopment programme that is tailor-made for a corporate pharmaceutical group.

The general objective of this research was to determine the effect of a selfdevelopment programme for managers in a corporate pharmaceutical environment.

\section{THEORETICAL BACKGROUND}

The ever-increasing changes in the political, social and economic environment have led organisations to recognise the need of continuously developing and investing in their employees. In response to this challenge there has been a stream of initiatives and ideas which have sought to promote ways in which 
employee development can be better integrated with organisational development, to form part of the corporate strategy. Since Senge (1990) placed the focus on creating "learning organisations", there has been a renewed interest in human resource development issues like improved communication, involvement and participation, development rather than training and staff empowerment. The emphasis on learning as a competitive advantage has renewed the importance of self-direction and personal responsibility in the development process.

Out of a myriad of principles that underpin employee development debates, two principles stand out among the rest, namely self-development and self-directed learning (Antonacopoulou, 2000: 492). Both these principles suggest that employees have the "power" to choose what to learn and how to develop themselves. This perspective is consistent with research observations (Boydell, 1976; Cunningham, 1999; Sutcliffe, 1988) that suggest that individuals cannot be forced to learn or develop against their will. Based on the principles of adult learning (Knowles et al., 1998), self-development emphasises choice and direction, and aligned to the tenet of human resource management it concentrates on the development of the individual rather than the collective. Unlike traditional development methods based on instruction and systematic training interventions, self-development has much in common with experiential and action learning theories which emphasise reflection, experimentation and a "meta-level" of understanding (Bova \& Kroth, 2001; Mumford, 1988; Revans, 1980). Therefore, key elements in the process of self-development are selfawareness, reflection and experimentation.

The Penguin Dictionary of Psychology (Reber, 1995: 702) defines selfdevelopment as "... generally, growth of self, movement toward emotional and cognitive maturity" and "... in Maslow's model, progress toward selfactualisation". Knowles clearly identifies andragogy as being rooted in humanistic and pragmatic philosophy, reflected by the influence of Maslow and Rogers (Holton, Swanson \& Naquin, 2001). As suggested by Pedler and Boydell $(1980,1981)$ and Pedler $(1984,1988)$ the uniqueness of self-development as a process of growth lies in the synthesis of three important dimensions, namely the concept of development, the notion of the whole person and personal responsibility.

The first dimension underlying the meaning of self-development is the association with the broader concept of development (for example the changes in the social structures that affect the individual's life span) (Haareven \& Adams, 1982; Hurley, 2002). Researchers exploring the structure of the development process have argued that development is a life-long process that involves gradual, incremental improvements and brusque revolutionary steps 
(Lievegoed, 1980). Each step influences the way individuals construct meaning about themselves and their experiences (Boydell, 1982). If experiences are going to result in developmental outcomes, the individual must be able to employ the necessary skills and resources to seek such experiences and to turn them into meaningful life events (Hurley, 2002; Kolb, 1984). Therefore, the focus of development within the self-development process is change, innovation and learning that take place, and not just the quantitative, incremental acquisition of knowledge and skills (Collin, 1994).

The second dimension of self-development is the emphasis on the whole person (i.e. the development of "self") and suggests that development is meaningful to the individual when personally significant goals are being pursued (Knowles, Holton \& Swanson, 1998; Murphy \& Young, 1995). Pedler and Boydell (1980: 171) point out that: "self-development takes place when the individual finds significance and personal meaning from particular events or experiences resulting from their actual or symbolic interaction with some part of their environment". Therefore, when setting self-development goals, the individual cannot be separated from what he or she is doing. Self-development should aim to integrate the person and the job role. The development process acquires meaning from the integration of the specific knowledge and skills relevant to the particular role and the feelings, intentions and actions of the individual.

The third dimension of self-development is personal responsibility. A central characteristic of self-development is choice on the part of the individual. Unlike conventional development processes that treat individuals as passive recipients, self-development places the individual at the forefront of the development process. The underlying argument is that development is not a matter of expertise, but a matter of a personal willingness and determination to commit oneself to a process that the individual values and believes in (Bagshaw \& Bagshaw, 2002; Hurley, 2002; Murphy \& Young, 1995; Pedler, 1984). The individual is therefore free to choose the goals, decide how to achieve them, initiate action for achieving them and evaluate success (Megginson \& Whitaker, 1998; Pedler, Burgoyne, \& Boydell, 1986). This dimension of self-development places the individual in control (in theory at least) of the self-development process.

The business argument for self-development rests on the idea that corporate survival in a rapidly changing economic environment requires resilient, changeoriented employees (Stickland, 1996: 33). The process of self-development generates a change mentality by first encouraging individuals to seek and foster change within themselves. This leads to the habit of learning to learn, and if conducted in the workplace the process becomes assimilated into the work ethic. Thus, people learn to be flexible and adaptable in meeting new business 
challenges. Self-development enables the organisation to keep up with the dynamics of change as it encourages managers to think positively about change and improvement (Temporal, 1984). Moreover, self-development encourages participation and may increase individuals' commitment to the organisation.

According to Temporal (1984), from the individual's point of view, selfdevelopment can enhance self-confidence and help to develop latent abilities that could improve initiative and work performance. Self-development could help individuals become more forthcoming and more prepared to speak their minds, which may improve their ability to solve problems and provide them with a broader outlook. Furthermore, self-development can encourage individuals to be more constructive in their relationships and motivate them to improve themselves. The psychological contract is changing and it is no longer based on loyalty, commitment and life-long employment (Herriot, Pemberton \& Hawtin, 1996). The "new" psychological contract centres on concepts such as self-sufficiency, self-responsibility and mutual viability. It aligns itself with the global business pulls towards autonomy and accountability as perceived in an era of restructuring lazy organisations and setting up independent business units to survive and contribute, or to be dispensed with immediately (Volpe, 1999: $30)$.

Based on the definition of self-development, the aim of a self-development programme is to move participants to an optimal, or at least a higher, state of psychological functioning. The characteristics of psychologically optimal functioning can be divided into intra- and interpersonal characteristics:

Intra-personally the optimally functioning individuals make sense out of life by judging internal and external stimuli as ordered, structured and consistent (Viviers, 1999). By means of control they handle external stimuli in daily life. They are integrated and self-sufficient, function in the here-and-now, apply their values in a flexible way, are sensitive to their emotions and show them spontaneously, without being compulsive or impulsive (Raskin \& Rogers, 1989). Their self-image is characterised by self-acceptance and positive selfregard (Raskin \& Rogers, 1989). The optimally functioning person accepts responsibility for what he or she does, for choices made and attitudes taken (Frankl, 1978; Raskin \& Rogers, 1989). In his or her working life this person has an active relationship with the organisation, is motivated towards his or her work and goals, and tries to perform to the best of his or her ability in order to perform (Viviers, 1999: 24). Furthermore, the optimally functioning person uses problem-focused strategies to cope with demands, that is, his or her actions taken during stressful events are aimed at changing the circumstances of the stressful event through problem-solving and seeking social support (Patterson, 2000: 277). 
The psychologically optimally functioning person maintains interpersonal relationships and social contact with different groups of people in society. This steady social tie with the broader community helps with status integration, coping with life problems and vital readjustment (Viviers, 1999: 24). In interpersonal relations the person who has undergone training in sensitive relation forming and facilitative communication will exhibit the elements fundamental to the process: empathy, respect, genuineness and concreteness.

\section{METHOD}

\subsection{Research design}

A two-group design with a pre-, post- and post-post-test was used (see Figure 1).

\section{Figure 1 The research design}

\begin{tabular}{||lcccc||}
\hline \multicolumn{1}{|c}{ Group } & Pre-test & Intervention & Post-test & Post-post-test \\
\hline $\begin{array}{l}\text { Experimental } \\
\text { Group }\end{array}$ & $\mathrm{Y} 1$ & $\mathrm{Xa}$ & $\mathrm{Y} 2$ & $\mathrm{Y} 3$ \\
Control Group 1 & $\mathrm{Y} 1$ & $\mathrm{Xb}$ & $\mathrm{Y} 2$ & $\mathrm{Y3}$ \\
\hline
\end{tabular}

Where

$$
\begin{aligned}
& \mathrm{Xa}=\text { self-development programme } \\
& \mathrm{Xb}=\text { no self-development programme }
\end{aligned}
$$

\subsection{The self-development programme}

The course manual was handed out to all participants one month prior to the workshop. Participants were requested to study the contents of the manual in preparation for the workshop, because time and work constraints made it difficult to engage pharmacy personnel in a full-time course. The programme for the workshop is given in Table 1. 


\section{Table 1 Workshop programme}

\begin{tabular}{|c|c|}
\hline TIME & ACTIVITY \\
\hline 08:00 & Tea and coffee \\
\hline \multirow[t]{2}{*}{ 08:15 } & $\begin{array}{l}\text { Participants are welcomed to the workshop and the hope is expressed } \\
\text { that they will find the day a meaningful experience. }\end{array}$ \\
\hline & $\begin{array}{l}\text { An initial exercise is done in which participants are asked their } \\
\text { expectations of the day, as well as norms by which the workshop } \\
\text { should be conducted. These are listed on a poster and put up in plain } \\
\text { sight of all. }\end{array}$ \\
\hline 08: 30 & $\begin{array}{l}\text { Each participant receives a poster with the instruction to make a } \\
\text { collage, using nothing but clippings from old magazines, with the title: } \\
\text { "Where am I in terms of my personal development at the moment and } \\
\text { where do I want to be one year from today?" }\end{array}$ \\
\hline 09:30 & $\begin{array}{l}\text { Each participant is given the opportunity to present their collage to the } \\
\text { rest of the group, and explain where they see themselves both now and } \\
\text { in the future. }\end{array}$ \\
\hline $10: 15$ & Tea and coffee \\
\hline $10: 25$ & $\begin{array}{l}\text { A lecture is presented on the MBTI }{ }^{\circledR} \text { and its terminology. All } \\
\text { participants already know their own MBTI }{ }^{\circledR} \text {-codes. }\end{array}$ \\
\hline $13: 00$ & Lunch \\
\hline $14: 00$ & $\begin{array}{l}\text { A lecture is given on the Carkhuff model of facilitative } \\
\text { communication. Afterwards participants are divided into groups of } \\
\text { three, with one playing the observer, a second the client, and a third the } \\
\text { facilitator. All participants are given the opportunity to practise the } \\
\text { skills and micro-skills as related to the model. }\end{array}$ \\
\hline $15: 20$ & Tea and coffee \\
\hline $15: 30$ & $\begin{array}{l}\text { Participants are asked to integrate all that was learned during the day } \\
\text { into a personal 5-point plan for self-development. They are free to sit } \\
\text { with a friend if they prefer. They are also asked to identify personal } \\
\text { strengths and weaknesses, as well as opportunities for and threats to } \\
\text { their personal self-development within their organis ation. }\end{array}$ \\
\hline $16: 00$ & $\begin{array}{l}\text { Participants complete an anonymous questionnaire about the } \\
\text { workshop, in order for its effectiveness to be measured and activities } \\
\text { adapted. After completing this questionnaire participants are free to go. }\end{array}$ \\
\hline
\end{tabular}




\subsection{Study population}

The study population was drawn from managers in the head office, managing directors, operational managers, area managers and other managers (e.g. retail and hospital pharmacies) of a pharmacy group. These managers $(N=35)$ were divided into an experimental and control group by means of probability sampling. Participant's academic qualifications ranged from Standard 8 (10 years of formal schooling), to a master's degree in either business or pharmaceutically related fields.

The characteristics of the study population are given in Table 2 .

Table 2 Characteristics of the study population

\begin{tabular}{||lccc||}
\hline \multicolumn{1}{|c}{ Variable } & $\begin{array}{c}\text { Experimental } \\
\text { group }\end{array}$ & Control group & Total \\
\hline Number of participants & 18 & 17 & 35 \\
Number of males & 2 & 6 & 8 \\
Number of females & 16 & 11 & 27 \\
Mean age & 35.3 & 35.3 & 35.3 \\
Mean years of service & 3.4 & 3.3 & 3.35 \\
\hline
\end{tabular}

\subsection{Measuring battery}

The Personal Orientation Inventory (POI) (Shostrom, 1974) was used to measure the intra-personal traits of individuals who function in a psychologically optimal way. Schulz (1994) asserts that the POI's reliability ranges from 0.41 to 0.82 . The POI has construct validity due to its significant correlation with the Sixteen Personality Factor Inventory (16PF). The time ratio and support ratio have a positive correlation with the emotional stability, assertiveness and enthusiasm items as measured by the 16 PF. Fouché and Rothmann (2000) found internal consistency coefficients varying between 0.24 and 0.75 at a tertiary education institution. Regarding the validity of the POI, she found that the construct validity of the POI was acceptable, except for Time ratio (Tc). Fouché and Rothmann (2000, p. 45) found acceptable levels of construct validity for most of the POI-scales. The two main scales, namely Time ratio (Tc) and Support ratio (I), are related to emotional stability and enthusiasm, but also lower levels of suspicion, anxiety, stress, neuroticism and emotional sensitivity.

The General Perceived Self-Efficacy Scale (GPSES) (Schwarzer, 1993) was used to measure participants' generalised self-efficacy. The GPSES consists of 
10 items. Schwarzer (1993) found alpha coefficients varying from 0.75 to 0.90 for the GPSES. By confirmatory factor analyses it was found that the scale was unidimensional in all sub-samples. The scale is not only reliable, it has also proven valid in terms of convergent and discriminant validity. Schwarzer (1993) found that the scale correlates positively with self-esteem and optimism and negatively with anxiety, depression and physical symptoms. In samples from 23 nations, the Cronbach alpha-coefficients ranged from 0.76 to 0.90 , with the majority in the high 0.80s. Rothmann and Van Rensburg (2001, p. 18) found that lower scores on generalised self-efficacy were related to a greater incidence of suicide ideation in police members.

The COPE Questionnaire (COPE) (Carver et al., 1989) was used to measure participants' coping strategies. The COPE is a multidimensional 53-item coping questionnaire that indicates the different ways that people cope in different circumstances (Carver et al., 1989). It measures 13 different coping strategies. Carver et al. (1989) reported Cronbach alpha coefficients for the COPE varying from 0.45 to 0.92 . All the sub-scales have sufficient levels of reliability except for Mental Disengagement, which measures lower than 0.60. Test-retest reliability varies from 0.46 to 0.86 and 0.42 to 0.89 (applied after two weeks).

A knowledge test was used to measure specific knowledge of broad terms, constructs and ideas as discussed in the manual. The test featured 50 multiplechoice questions, which participants had to answer by in each instance by choosing one of 4 or 5 possible answers. The second part of the test consisted of written questions the participant had to answer. These questions were still directly related to the content of the manual.

\subsection{Statistical analysis}

The statistical analysis was done by means of the SAS computer program (SAS Institute, 2000). Descriptive and inferential statistics were used to analyse the results. The Wilcoxon rank sum test was used to determine the significance of differences between the experimental and control groups. This indicates whether there are meaningful differences for changes in the experimental and control groups. The signed rank Wilcoxon test was used to determine the significance of differences within the experimental and control groups, between the pre-, post, and post-post testing. Results are regarded as significant if the p-values are smaller than 0.50, since this is the cut-off for most behavioural science research (Christensen \& Stoup, 1991: 231). The p-values obtained (two-sided test) were divided by two, to transform them to a one-sided test (since the alternative hypothesis is indicative of direction) (Plug et al., 1988: 70). This value is then multiplied by three (the Bonferroni correction) because of the use of a post-post 
test. If the final $\mathrm{p}$-values are statistically significant $(\mathrm{p}<0.05)$ the practical significance $(d)$ for the results was calculated (Cohen, 1988).

\section{$4 \quad$ RESULTS}

Table 3 indicates the significance of differences between the pre- and post-tests of the experimental and control groups on the POI.

Table 3 Significance of differences between the experimental and control groups on the POI

\begin{tabular}{||cccccccc|}
\hline \multicolumn{1}{|c}{ Item } & \multicolumn{2}{c}{$\begin{array}{c}\text { Pre-test - Post- } \\
\text { test }\end{array}$} & \multicolumn{2}{c}{$\begin{array}{c}\text { Pre-test - Post- } \\
\text { post-test }\end{array}$} & \multicolumn{2}{c|}{$\begin{array}{c}\text { Post-test - } \\
\text { Post-post-test }\end{array}$} \\
\hline & $p$ & $d$ & $p$ & $d$ & $p$ & $d$ \\
Time ratio (Tc) & 0.48 & - & 1.20 & - & 0.32 & - \\
Self-actualising value (Sav) & 0.11 & - & 1.01 & - & 0.48 & - \\
Existentiality (Ex) & 0.61 & - & 0.87 & - & 1.39 & - \\
Support ratio (I) & 1.38 & - & 0.15 & - & 0.26 & - \\
Feeling reflection (Fr) & 0.81 & - & $0.03^{+}$ & $0.80^{* *}$ & $0.05^{+}$ & $0.60^{*}$ \\
Spontaneity (S) & 1.12 & - & 1.32 & - & 1.10 & - \\
Self-regard (Sr) & 0.71 & - & 1.21 & - & 0.86 & - \\
Self-acceptance (Sa) & 0.35 & - & 1.50 & - & 0.36 & - \\
View of Human Nature (Nc) & 0.39 & - & 1.33 & - & 0.27 & - \\
Synergy (Sy) & $0.02^{+}$ & $0.84^{* *}$ & 0.49 & - & 0.49 & - \\
Acceptance of Aggression (A) & 1.34 & - & 0.88 & - & 0.98 & - \\
Capacity for intimate contact & 1.50 & - & 0.40 & - & 0.49 & - \\
(C) & & & & & & \\
\hline
\end{tabular}

$+\quad$ Statistically significant: $p<0.05$

* Practically significant: $d \geq 0.50$ (medium effect)

** Practically significant: $d \geq 0.80$ (large effect)

Table 3 shows that a statistically significant difference between the experimental and control groups regarding Synergy (Sy) was found between the pre- and posttest. This difference is also practically significant (large effect). The experimental group showed a significant increase in Synergy directly after completing the self-development programme. The results show that the individuals who participated in the self-development programme (compared 
with those who were not involved) had a greater synergistic awareness, which means to see opposites in life as meaningful, rather than as antagonistic.

Regarding the comparison of the pre- and post-post test and the post- and postpost-test, Table 3 indicates a statistically significant difference between the experimental and control groups regarding Feeling reactivity (Fr). This difference is also practically significant (large effect). The results show that the individuals who participated in the self-development programme (compared with those who were not involved) had become more sensitive to their own feelings and needs two months after completing the programme.

Table 4 shows the significance of differences between the pre- and post-tests of the experimental and control groups on the GPSES.

Table 4 Significance of differences between the experimental and control groups on the GPSES

\begin{tabular}{|c|c|c|c|c|c|c|c|}
\hline \multicolumn{2}{|c|}{ Item } & \multicolumn{2}{|c|}{ EG $(n=18)$} & \multicolumn{2}{|c|}{ CG $(n=17)$} & \multirow[t]{2}{*}{$p$} & \multirow[t]{2}{*}{$d$} \\
\hline & & Mean & SD & Mean & SD & & \\
\hline $\begin{array}{l}\text { Pre-test } \\
\text { test }\end{array}$ & - Post- & 2.22 & 0.54 & -0.12 & 3.17 & 0.13 & \\
\hline $\begin{array}{l}\text { Pre-test - } \\
\text { post-test }\end{array}$ & - Post- & 3.11 & 0.47 & 0.18 & 2.32 & $0.03^{*}$ & $1.26^{* *}$ \\
\hline $\begin{array}{l}\text { Post-test } \\
\text { post-test }\end{array}$ & - Post- & 0.89 & 2.49 & 0.29 & 2.68 & 0.75 & - \\
\hline
\end{tabular}

Table 4 indicates that there are no significant differences between the experimental and control groups for the pre- and post-tests regarding the GPSES. However, a statistically significant difference was found regarding the change between the pre-test and post-post-test of the experimental and control groups on the GPSES. This difference is also practically significant (large effect). The results show that the participants in the self-development programme (compared with those who were not involved) were more inclined to believe that they were able to perform novel or difficult tasks two months after completing the training programme. This would probably facilitate goal setting, effort investment and persistence in the face of barriers and recovery from setbacks. There is no statistically significant difference between the experimental and control groups regarding the GPSES between the post- and post-post-testing. 
The significance of differences between the pre-, post- and post-post-tests of the experimental and control groups on the COPE is given in Table 5.

Table 5 Significance of differences between the experimental and control groups on the COPE

\begin{tabular}{|c|c|c|c|c|c|c|}
\hline \multirow[t]{2}{*}{ Item } & \multicolumn{2}{|c|}{$\begin{array}{l}\text { Pre-test - } \\
\text { Post-test }\end{array}$} & \multicolumn{2}{|c|}{$\begin{array}{c}\text { Pre-test - } \\
\text { Post-post-test }\end{array}$} & \multicolumn{2}{|c|}{$\begin{array}{c}\text { Post-test - } \\
\text { Post-post-test }\end{array}$} \\
\hline & $p$ & $d$ & $p$ & $d$ & $p$ & $d$ \\
\hline Active coping & 0.15 & - & 0.07 & - & 0.63 & - \\
\hline Planning & 0.47 & - & 1.50 & - & 0.41 & - \\
\hline $\begin{array}{l}\text { Suppressing of competing } \\
\text { activities }\end{array}$ & 0.29 & - & 0.09 & - & 1.50 & - \\
\hline Restrained coping & 0.33 & - & 0.39 & - & 1.04 & - \\
\hline $\begin{array}{l}\text { Seeking social support for instru- } \\
\text { mental reasons }\end{array}$ & 0.10 & - & 1.14 & - & 0.28 & - \\
\hline $\begin{array}{l}\text { Seeking social support for emo- } \\
\text { tional reasons }\end{array}$ & 0.44 & - & 1.32 & - & 0.17 & - \\
\hline $\begin{array}{l}\text { Positive reinterpretation and } \\
\text { growth }\end{array}$ & 0.82 & - & 1.04 & - & 0.96 & - \\
\hline Accept & 1.24 & - & 1.28 & - & 1.50 & - \\
\hline Turning to religion & 1.32 & - & 1.16 & - & 1.45 & - \\
\hline $\begin{array}{l}\text { Focus on and venting of } \\
\text { emotions }\end{array}$ & 0.28 & - & 0.66 & - & 0.26 & - \\
\hline Denial & 0.64 & - & 1.50 & - & 0.36 & - \\
\hline Behavioural disengagement & 1.50 & - & 0.82 & - & 0.96 & - \\
\hline Mental disengagement & 1.35 & - & 0.91 & - & 0.73 & - \\
\hline Alcohol/drug disengagement & 1.50 & - & 0.95 & - & 0.54 & - \\
\hline
\end{tabular}

Table 5 shows that no significant differences were found between the various tests on the COPE.

The significance of the differences between the pre-, post- and post-post-tests of the experimental and control groups on the Knowledge test is given in Table 6. 
Table 6 Significance of differences between the pre- and post-tests of the experimental and control groups on the knowledge test

\begin{tabular}{|c|c|c|c|c|c|c|}
\hline \multirow[t]{2}{*}{$\overline{\text { Item }}$} & \multicolumn{2}{|c|}{ EG $(n=18)$} & \multicolumn{2}{|c|}{ CG $(n=17)$} & \multirow[t]{2}{*}{$p$} & \multirow[t]{2}{*}{$d$} \\
\hline & Mean & SD & Mean & SD & & \\
\hline Pre-test - Post-test & 20.94 & 10.20 & -1.31 & 7.67 & $0.00^{*}$ & $2.18^{* *}$ \\
\hline $\begin{array}{l}\text { Pre-test - Post-post- } \\
\text { test }\end{array}$ & 24.05 & 12.83 & -0.57 & 5.44 & $0.00^{*}$ & $1.92^{* *}$ \\
\hline $\begin{array}{l}\text { Post-test - Post-post- } \\
\text { test }\end{array}$ & 3.11 & 6.99 & 0.74 & 7.36 & 0.29 & - \\
\hline
\end{tabular}

A statistically significant difference was found between the pre- and post-tests of the experimental and control groups on the Knowledge test. Table 6 also shows a statistically significant difference regarding the change in knowledge between the pre- and post-post-tests. Both these differences were practically significant (large effects). Members of the experimental group (compared with the control group) obtained more knowledge of self-development through the self-development programme. Although no increase in knowledge of selfdevelopment was found between the post- and post-post-tests, the increase in knowledge of the experimental group was significantly higher when the pre- and post-post-tests were compared.

The qualitative impressions of participants of the self-development programme are given below. This information was gathered from evaluation forms participants completed after the workshop.

The most important things learned from the self-development programme. Half of the participants said that the most important thing they had learned was "more about the self". Two further themes that received support were the need for continuous self-development and ongoing evaluation of personal development needs, as well as greater tolerance for and empathy with other people. Participants said firstly that they now understood that self-development had to be a personal process linked to the organisation's needs, but also benefiting the individual. Secondly, they mentioned how colleagues now seemed "closer" and "more human" - this was typically expressed by words such as "everyone's got problems", and "there is a place in the sun for everyone". Furthermore, participants mentioned a greater awareness of personal actions, thoughts and preferences. 
- Meaningful activities. Half of the participants said that the collage was the most meaningful activity. The usefulness of this activity was very apparent - some participants reacted quite emotionally to their collages, and others mentioned how they appreciated everyone's honesty. The second most meaningful activity was the training in facilitative communication. Mostly participants considered this useful because they were taught specific skills which they felt they would be able to use outside the workshop.

- Opinions regarding the successfulness of the self-development programme. Except for one participant who did not complete this question, everyone thought that the programme was successful. The reason cited most for the success of the programme was the fact that participants had learned more and felt better about themselves and/or other people. Furthermore, participants said that they thought the programme was successful because of the other participants' reaction and participation. Mention was made of greater cohesion and empathy within the group at the end of the day. Also, participants felt that the programme was a success because they now had a better understanding of the concept of, and need for, self-development.

\section{DISCUSSION}

The self-development programme contributed to members' synergistic awareness. This means that directly following the programme members had a higher tendency to see seemingly antagonistic opposites as meaningfully related. With statements such as "there is a place in the sun for everyone" emerging from the qualitative data, participants are perhaps feeling less competition amongst themselves, by also stating that there is greater compassion and understanding within the group. In defining self-development during the workshop, participants included in the definition the possibility of regression or pain occurring before growth can take place. This is another example of seeming opposites finding integration within participants. The increase in synergistic awareness indicates that participants experienced more meaningfulness in their lives after completing the self-development programme. This is a result of participants making contact with their real selves in an atmosphere of respect and understanding (Raskin \& Rogers, 1989).

A definite increase took place in participants' reflections on feelings both directly following the workshop and even after two months following it. This shows that participants became more sensitive towards their own needs and feelings following this programme (Leitschuh \& Rawlins, 1991). By becoming 
more sensitive towards their own feelings, participants would be less likely to project them to other people. It also seems logical that a greater sensitivity towards own feelings would lead to a greater sensitivity towards the feelings of others. Again, this is reflected in the qualitative data, with statements such as "everyone's got problems". With half of the participants stating that the most important thing they had learned from the programme was "more about myself", this long-term effect in reflecting on feelings seems logical. It can thus be stated that the programme fosters a greater sensitivity within participants to their personal needs and emotions, and to those of others.

Quantitative results indicate that two months after the self-development programme, participants showed greater self-efficacy. This means that the programme contributed to participants' gaining more faith in their personal skills and abilities. In line with the findings of Hobfoll (2001), it can be stated that the self-development programme increased the resources of participants, which would be beneficial in terms of work outcomes, especially if it is considered that having one resource is linked to having others (Rothmann \& Van Rensburg, 2001).

It would seem that an increase in self-efficacy addresses a fundamental need in self-development. If participants gained faith in themselves, it would affect the very way they look at themselves, their work, their organisation, and definitely at their contributions (Schwarzer, 1992). This seems highly significant: would persons who have more faith in themselves not be more motivated to sustain their efforts in the face of adversity? The effect of greater self-efficacy in the work situation will lead these persons to make greater contributions if they now feel that their contributions can be meaningful. One can imagine this increase in self-efficacy to be reflected in all aspects of these persons' lives: their behaviour should show more self-confidence, their emotions should be better controlled, and physically they should show greater determination (Schwarzer, 1999).

Directly following the programme, and even after two months, participants showed greater knowledge regarding the elements discussed in the selfdevelopment manual. It could be argued that greater knowledge of psychological health, interpersonal effectiveness, management of conflict, personality preferences and creative problem solving would lead the person to be more aware of all of these aspects. Knowledge about self-development could facilitate the long-term development on intra- and interpersonal level. This knowledge is also reflected in the qualitative data, with participants stating that they now saw the need and relevance of self-development, felt that they would be better able to successfully communicate with the skills of facilitative communication, and felt that "everyone has a right to their preference". One should also keep in mind that exposure to constructs and ideas unfamiliar to 
participants might actually stimulate and motivate them to learn more about aspects that were of interest to them.

Despite the promising results of the self-development programme regarding knowledge as well as some intra-personal and interpersonal characteristics, there were other characteristics and coping strategies that showed no significant changes after participants had gone through the self-development programme. However, it should be taken into account that this intervention was a first effort to stimulate the self-development of managers in a corporate pharmacy group. More development could take place over time and with more intensive interventions.

Regarding the qualitative evaluation, it seems that the programme contributed to learning about the self, realising the importance of self-development, developing tolerance and empathy for other people and increasing self-awareness. Participants regarded the collage as a meaningful activity. The fact that the participants were satisfied with the arrangements of the self-development programme as well as the facilitation and presentation thereof helped create an atmosphere conducive to learning.

Various limitations regarding this research have been identified. Firstly, the empirical study only included members of a single organisation and the results thus cannot be generalised to other organisations. Secondly, the effect of the pretest was not eliminated. Thirdly, the content of a self-development programme is of such a nature that it is difficult to deal successfully with all aspects in a single day. Furthermore, the results of a self-development programme are not meant to be immediate. Ideally a longitudinal study should have been undertaken to measure participants perhaps six months or a year after completion of the programme to determine whether long-term change had been effected.

\section{RECOMMENDATIONS}

The self-development programme should be presented to all the managers in the corporate pharmaceutical group. The programme should focus on intra-personal and interpersonal growth, as well as on knowledge of self-development. More contact time should be allocated to the self-development programme. It was evident during the presentation that participants had the need to discuss their personal growth issues in a facilitative atmosphere. Both the presenters and the co-participants in the programme play an important role in this regard. This is something that participants alluded to, and is also recommended because of the nature of the content of such a programme. The pain or uneasiness that comes to the fore when one has to do self-investigation, could be better handled, perhaps 
in personal development sessions, if more time were available. Selfdevelopment should not be an exclusive management development initiative. All levels of employees could learn and benefit from this type of programme. If, for example, levels of self-efficacy could be improved across the board throughout the organisation, this would contribute to organisational effectiveness.

Longitudinal research should be undertaken to determine the long-term effects of a self-development programme. As mentioned, the results of a selfdevelopment programme are not meant to be instantaneous. Follow-up measurement perhaps six months or a year after the programme would further illuminate the true effect. Research should be conducted into other learning approaches that could be incorporated into this type of programme. A growth group and personal interviews could have contributed to the further successfulness of this programme. Evaluation studies of self-development programmes should be conducted with larger samples and in more pharmaceutical groups.

\section{REFERENCES}

1 AMOS, T.L. \& MATHER, D. (1998) "Interpersonal competence: Critical to effective communication with patients," South African Pharmaceutical Journal, 65: 9-11.

2 ANTONACOPOULOU, E.P. (2000) "Employee development through self-development in three retail banks," Personnel Review, 29: 491-508.

3 BAGSHAW, M., \& BAGSHAW, C. (2002) "Radical self-development: A bottom up perspective", Industrial and Commercial Training, 34: 194-7.

4 BOVA, B., \& KROTH, M. (2001) "Workplace learning and generation X", Journal of Workplace Learning, 13: 57-65.

5 BOYDELL, T. (1976) "Experimental Learning. Manchester Monographs: Volume 5" Department of Adult Education, University of Manchester, Manchester.

6 BOYDELL, T. (1982) “Development." MEAD Journal, 13(1): 10-32.

7 CARVER, C.S., SCHEIER, M.F. \& WEINTRAUB, J.K. (1989) "Assessing coping strategies: A theoretically based approach", Journal of Personality and Social Psychology, 57: 267-83.

8 CHRISTENSEN, L.B., \& STOUP, C.M. (1991) Introduction to Statistics for the Social and Behavioral Sciences ( ${ }^{\text {nd }}$ ed.) Pacific Grove, CA: Brooks/Cole.

9 CILLIERS, F.V.N. \& WISSING, M.P. (1993) "Sensitiewe relasievorming as bestuursdimensie: Die evaluering van "n ontwikkelingsprogram", Tydskrif vir Bedryfsielkunde, 19(1): 5-10. 
10 COHEN, J. (1988) Statistical Power Analysis for the Behavioral Sciences (Rev. ed.) Orlando, FL: Academic Press.

11 COLLIN, A. (1994) "Learning and Development", In I. Beardwell \& L. Holden (eds.) Human Resource Management: A Contemporary Perspective, London: Pitman Publishing.

12 CUNNINGHAM, I. (1999) The Wisdom of Strategic Learning: The Selfmanaged Learning Solution ( $2^{\text {nd }}$ ed.) London: Gower.

13 DAY, B \& MATTHES, W. (1992) "A Jungian stage theory of individual development in personal growth groups", The Journal for Specialists in Group Work, 7(2): 168-82.

14 ELS, D. \& LINDE L. \& ROTHMANN, S. (2001) "Die evaluering van "n ontwikkelingsprogram gerig op werknemers se lokus van beheer", Tydskrif vir Bedryfsielkunde, 27(3): 24-29.

15 FERGUSON, J. (1998) International Mutual Recognition: Concept and Barriers, Paper delivered at the $3^{\text {rd }}$ International Conference on Pharmaceutical Competence, New South Wales, Australia.

16 FOUCHE, W.J. \& ROTHMANN, S. (2000) "Die interne konsekwentheid en konstrukgeldigheid van die persoonlike oriëntasievraelys vir 'n groep universiteitstudente", Journal of Industrial Psychology, 26(1): 39-45.

17 FRANKL, V.E. (1978) Waarom Lewe Ek?, Kaapstad: HAUM.

18 GRANT, J. (2000) "Continuing professional development in a modern profession", Paper delivered at the $4^{\text {h }}$ International Conference on LifeLong Learning in Pharmacy, Templepatrick, Northern Ireland.

19 HAAREVEN, T.K., \& ADAMS, K.J. (1982) Ageing and Life Course Transition: An Inter-disciplinary Perspective”, London: Tavistock.

20 HERRIOT, P., PEMBERTON, C., \& HAWTIN, E. (1996) "The career attitudes and intentions of managers in the finance sector", British Journal of Management, 7(2): 181-90.

21 HOBFOLL, S.E. (2001) "The influence of culture, community and the nested-self in the stress process: advancing conservation of resources theory", Applied Psychology: An International Review, 50: 337-69.

22 HOLTON, E.F., SWANSON, R.A. \& NAQUIN, S.S. (2001) "Andragogy in practice: clarifying the andragogical model of adult learning." Performance Improvement Quarterly, 14(1): 118-43.

23 HURLEY, R.F. (2002) "Putting people back into organizational learning", The Journal of Business and Industrial Marketing, 17(4): 270-81.

24 JORGENSEN, L.I. \& ROTHMANN, S. (1998) "Die evaluering van 'n opleidingsprogram t.o.v. interpersoonlike vaardighede", Tydskrif vir Ekonomiese en Bestuurswetenskappe, 1:377-389.

25 JUNG, C.G. (1971) "Psychological types", In J. Campbell (ed.) The Portable Jung, New York: Viking.

26 KNOWLES, M., HOLTON, E. \& SWANSON, R. (1998) The Adult Learner $\left(5^{\text {th }}\right.$ ed.) Houston, TX: Gulf Publishing. 
27 KOLB, D.A. (1984) Experimental Learning: Experience as the Source of Learning, Englewood Cliffs, NJ: Prentice-Hall.

28 LEITSCHUH, G.A., \& RAWLINS, M.E. (1991) "Personal orientation inventory correlated with physical health", Psychological Reports, 69: 687-90.

29 LIEVEGOED, B.C. (1980) The Developing Organisation, Millbrae, CA: Celestial Arts.

30 MEGGINSON, D. \& WHITAKER, V. (1998) Cultivating Self-development, London: IPD.

31 MEYER, W.F., MOORE, C. \& VILJOEN, H.G. (1994) Persoonlikheidsteorieë: Van Freud tot Frankl, Johannesburg: Lexicon.

32 MÖLLER, J.S., ROTHMANN, S., ROTHMANN, J.C., COETZER, E.P. \& SWART, L.M. (2000) "Developing pharmacists in a corporate environment: The role of individual and organisational factors", Poster session presented at the $4^{\text {th }}$ International Conference on Pharmaceutical Competence, Ottawa, Canada.

33 MUMFORD, A. (1988) "Learning to learn and management selfdevelopment", In M. Pedler, J. Burgoyne \& Boydell, T. (eds.) Applying Self-development in Organisations, New York: Prentice Hall.

34 MURPHY, H.J. \& YOUNG, J.D. (1995) "Management self-development and small business: Exploring emergent issues", Management Learning, 26: 319-30.

35 OLIVIER, M. \& ROTHMANN, S. (1999) "The development of an internal locus of control in employees in the manufacturing sector", South African Journal of Economic and Management Sciences, 2: 476-91.

36 PATTERSON, G.T. (2000) "Demographic factors as predictors of coping strategies among police officers", Psychological Reports, 87: 275-83.

37 PEDLER, M. \& BOYDELL, T. (1980) "Is all management development self-development?" In J. Beck \& C. Cox (eds.) Advances in Management Education: 165-96, Chichester: Wiley.

38 PEDLER, M. \& BOYDELL, T. (1981) “What is self-development?" In T. Boydell \& M. Pedler (eds.) Management Self-development: Concepts and Practices. Aldershot: Gower.

39 PEDLER, M. (1984) "Management self-development", In B. Taylor \& H. Lippit (eds.) Handbook of Management Development. London: McGrawHill.

40 PEDLER, M. (1988) "Self-development and Work Organisations." London: Prentice-Hall.

41 PEDLER, M., BURGOYNE, J., \& BOYDELL, T. (1986) A Manager's Guide to Self-development ( ${ }^{\text {nd }}$ ed.) London: McGraw-Hill.

42 PLUG, C., MEYER, W.F., LOUW, D.A., \& GOUWS, L.A. (1998) Psigologiewoordeboek (3de uitg.) Johannesburg: Lexicon. 
43 RASKIN, N.J., \& ROGERS, C.R. (1989) "Person-centered therapy", In R.J. Corsini \& D. Wedding, D. (eds.) Current Psychotherapies $\left(4^{\text {th }}\right.$ ed.) Itasca, IL: Peacock.

44 REBER, A.S. (ed.) (1995) The Penguin Dictionary of Psychology $\left(2^{\text {nd }}\right.$ ed.) London: Penguin Books.

45 REVANS, R.W. (1980) Action Learning: New Techniques for Managers, London: Blond and Briggs.

46 ROGERS, C.R. (1961) On Becoming a Person: A Therapist's View of Psychotherapy, Boston, MA: Houghton-Mifflin.

47 ROGERS, C.R. (1973) Client-centered Therapy, London: Constable.

48 ROTHMANN, J.C., ROTHMANN, S., VAN RENSBURG, S. \& MALAN, A.M. (2000) "The role of personality dispositions and career anchors in pharmacist development", Poster presented at the $4^{\text {th }}$ International Conference on Pharmaceutical Competence, Ottawa, Canada.

49 ROTHMANN, S. \& SIEBERHAGEN, G. (1997) "Die samestelling en evaluering van "n groepfasiliteringskursus", Tydskrif vir Bedryfsielkunde, 23(3): 9-14.

50 ROTHMANN, S. (1999) "The evaluation of a training programme in facilitation at a tertiary education institution", Management Dynamics: Contemporary Perspectives, 8(4): 33-50.

51 ROTHMANN, S., \& VAN RENSBURG, P. (2001) "Correlates of suicide ideation in the South African Police Services in the North West Province." Poster session presented at the $13^{\text {th }}$ Conference of the South African Institute for Management Sciences, Stellenbosch, 7-9 September.

52 ROTHMANN, S., BASSON, W.D., \& ROTHMANN, J.C. (2000) "The personality preferences of pharmacy students and lecturers at a tertiary education institution", International Journal of Pharmacy Practice, 8: 225-33.

53 ROTHMANN, S., SIEBERHAGEN, G. \& CILLIERS, F.V.N. (1998) "Die kwalitatiewe effek van 'n groepfasiliteringskursus", Tydskrif vir Bedryfsielkunde, 24(3): 7-13.

54 SAS INSTITUTE (2000) The SAS System for Windows Release 8, Cary, NC: SAS Institute Inc.

55 SCHULTZ, D. (1977) Growth Psychology: Models of the Healthy Personality, New York: Van Nostrand.

56 SCHULZ, G.M. (1994) "Reliability and validity of the personal orientation inventory in South Africa", Unpublished master's dissertation, University of South Africa, Pretoria.

57 SCHWARZER, R. (1992) Self-efficacy: Thought Control of Action, Washington, DC: Hemisphere.

58 SCHWARZER, R. (1993) Measurement of Perceived Self-efficacy: Psychometric Scales for Cross-cultural Research", Berlin: Freie Universität Berlin. 
59 SCHWARZER, R. (1999) "Self-regulatory processes in the adoption and maintenance of health behaviors: The role of optimism, goals and threats", Journal of Health Psychology, 4(2): 115-27.

60 SENGE, P.M. (1990) "The leaders' New Work: Building learning organisations", Sloan Management Review: 7-23.

61 SHOSTROM, E. L. (1974) Manual for the Personal Orientation Inventory (rev. ed.) San Diego, CA: Edits.

62 STICLAND, R. (1996) "Self-development in a business organization." Journal of Managerial Psychology, 11(7): 30.

63 STRÜMPFER, D.J.W. (2000) "Psychometric properties of an instrument to measure resilience", Paper presented at the Annual Conference of the Society for Industrial Psychology, Pretoria.

64 SUTCLIFFE, G.E. (1988) Effective Learning for Effective Management, London: Prentice-Hall.

65 TEMPORAL, P. (1984) "Helping self-development to happen”, In C. Cox \& J. Beck, (eds.) Management Development: Advances in Practice and Theory, Manchester: Wiley.

66 VIVIERS, A.M. (1999) "Die persoonlikheidsoriëntasieprofiel van die salutogenies-funksionerende mens", Journal of Industrial Psychology, 25(1): 21-26.

67 VOLPE, R. (1999) “The new psychological contract", People Dynamics, 17(4): 28-32. 